\title{
Genomes, gender and the psychodynamics of a scientific crisis: a psychoanalytic reading of Michael Crichton's genomics novels
}

\author{
H.A.E. (Hub) Zwart
}

To cite this article: H.A.E. (Hub) Zwart (2015) Genomes, gender and the psychodynamics of a scientific crisis: a psychoanalytic reading of Michael Crichton's genomics novels, New Genetics and Society, 34:1, 1-24, DOI: 10.1080/14636778.2014.986570

To link to this article: http://dx.doi.org/10.1080/14636778.2014.986570

巴nublished online: 02 Dec 2014.

Submit your article to this journal $\square$

Џll Article views: 331

Q View related articles $\square$

View Crossmark data ¿ 


\title{
Genomes, gender and the psychodynamics of a scientific crisis: a psychoanalytic reading of Michael Crichton's genomics novels
}

\author{
H.A.E. (Hub) Zwart* \\ Department of Philosophy, Faculty of Science, Radboud University Nijmegen, \\ Nijmegen, The Netherlands
}

(Received 27 June 2014; final version received 22 October 2014)

\begin{abstract}
Michael Crichton (1942-2008) was a prolific writer of "science novels", portraying the psychodynamics and sociodynamics of genomics and other NBIC (Nanotechnology, Biotechnology, Information technology and Cognitive science) fields, fostering critical reflection on their societal dimensions. Science novels may serve as "literary experiments", as windows into the (future) impacts of current research. Although on the surface level Crichton's books may be seen as entertaining bestsellers, an in-depth reading allows them to emerge as exploratory exercises, usable as course material for science students. To open up this "deeper" dimension, I read Crichton's work from a psychoanalytic angle, focusing on typical scenes and themes, such as the idea of a scientific crisis, geneticization and gender role reversal. The core question of a typical Crichton novel usually is: what will happen when a new laboratory research field suddenly comes out into the open? Notably, the gender dimension reflects and exemplifies the fascinations and concerns with contemporary technoscience addressed by him.
\end{abstract}

Keywords: Michael Crichton; science novels; psychoanalysis; Jurassic Park; genomics; science and gender; scientific revolution; scientific crisis

\section{Introduction: why Crichton?}

Every year since 2003, I have taught a philosophy course for science students coming from various disciplines entitled Literature and Science. At our university, science students are required to take mandatory courses in philosophy, and this is one of the options. "Science novels" serve as literary windows that bring the challenges and dilemmas of contemporary research practices into view, fostering critical reflection on their societal dimensions and implications. ${ }^{1}$

The late Michael Crichton (1942-2008) is a prolific representative of this genre and frequently read by students following my course. The question of why

\footnotetext{
*Email: h.zwart@science.ru.nl
} 
Crichton's books are popular among students seems an easy one to answer. The language is lively and accessible, the narratives involve a fair amount of drama and several of his books have been made into movies. Indeed, his novels are usually written in a cinematic vein, with powerful images (Nerlich, Clarcke, and Dingwall 2001; Nerlich 2005) and non-stop action. Last but not least, Crichton was trained as a scientist himself. As a Harvard graduate and former postdoc at the Salk Institute in San Diego, he was sufficiently au courant with the technicalities and vocabularies of laboratory life to act as a credible portrayer of cutting-edge research. He wrote about gene sequencing, enzymes, bacteriophages and computer programs in ways that (future) scientists find credible and easy to engage with (although some novels are technically speaking more credible than others). In addition, however, his work draws attention to important societal dimensions of current technosciences and their (progressive or disruptive) consequences, such as commercialization (the increased entanglement of academic research with global venture capitalism), "geneticization" (the tendency to redefine both life and human existence in terms of genes and genomes) and shifting gender roles. Moreover, his novels analyze the intimate ways in which these trends are interconnected.

Although Crichton is often dismissed by academics as a "lowbrow" novelist - a term which happens to be a legacy from the eugenics era (Whalan 2007, 89) - I introduce him to my students as the "Jules Verne of our time", not only because of his immense popularity and his profound interest in machines, but also because his writings provide an encyclopedic panorama of contemporary research fields, as is indicated by the list of titles (a selection) displayed below:

\begin{tabular}{lll}
\hline Year & \multicolumn{1}{c}{ Title } & \multicolumn{1}{c}{ Research fields (among others) } \\
\hline 1969 & Andromeda Strain & Bacteriology \\
1972 & Terminal Man & Psychosurgery \\
1980 & Congo & Primate ethology, ICT, geography, psychology \\
1987 & Sphere & Psychology, oceanography \\
1990 & Jurassic Park & Genomics, paleontology, complexity theory \\
1994 & Disclosure & ICT \\
1995 & Lost World & Genomics, paleontology, complexity theory \\
1996 & Airframe & Thermodynamics \\
1999 & Timeline & Archeology \\
2002 & Prey & Nanotechnology \\
2004 & State of Fear & Environmental science, climate research, political science \\
2006 & Next & Personalized genomics, behavioral genomics \\
2011 & Micro & Entomology, nanotechnology \\
\hline
\end{tabular}

More importantly, however, Crichton assesses these research fields from a specific angle, conveying the idea that we currently witness a period of scientific revolution, giving rise to a series of (potentially disruptive) scientific crises. Indeed, the concept of a scientific crisis (how it is produced, but also addressed 
by science) determines the structure of most of his books. His novels revolve around latent explosive tensions that suddenly erupt in the form of dramatic and possibly lethal symptoms, studying the responses they evoke and suggesting possible interventions to address them.

To bring this "deeper" societal relevance of Crichton's science novels (often discredited as mere "entertainment") to the fore, I will read his work from a psychoanalytic perspective, using concepts coined by Freud, Lacan and others to discern and assess the ways in which some of the major drives, anxieties and concerns connected with technoscience surface in Crichton's oeuvre. I will focus mainly on his life sciences novels, notably his genomics ${ }^{2}$ books. First, I will briefly outline my (psychoanalytic) frame of reference and methodology. Next, I will describe Crichton's concept of a "scientific crisis" in more detail, focusing on the tension between "indoors" (lab) and "outdoors" (field) science. This will be elucidated through a first case study, namely Crichton's famous genomics novel Jurassic Park (1990). I will consider how, in this novel, by bringing cutting-edge laboratory research out into the open (in the form of a "field experiment"), the latent disruptive crisis of contemporary biology suddenly manifests itself. Eventually, however, my article will predominantly explore the ways in which, in Crichton's work, these transitions are interwoven with gender issues. The contention here is that, for Crichton, the current, highly transformative scientific revolution not only involves automated sequencing and commercialization, but also redefines gender dynamics, within research practices first of all, but also within knowledge societies as such.

\section{Why psychoanalysis?}

Is psychoanalysis outdated? This question is explicitly raised by Žižek ([2006] 2007) in one of his introductions to Lacan. In an era of high-tech brain research and psychopharmaceuticals, ${ }^{3}$ psychoanalysis seems to be something of the past. And yet, Žižek claims that it is only today that the time of psychoanalysis has really come (2). In fact, Freud himself already suggested that psychoanalysis (besides its therapeutic value) may increasingly contribute to our understanding of culture, society and language ([1926] 1948, 293) - and I would add - of science. This is taken up by Lacan who argued that the ultimate "subject" of psychoanalysis is, first and foremost, the scientific "subject", as scientific crises often entail significant personal drama, claiming individual scientists (Mayer, Cantor, Boltzmann, etc.) as casualties $(1966,869,870)$.

Moreover, psychoanalysis represents a particular way of reading and questioning textual materials, pointing out symptoms, latent tensions, uneasiness and contradictions. And it has an impressive track record when it comes to using novels to further our understanding of contemporary culture, including science. ${ }^{4}$ Science novels may play a role in understanding science similar to the role played by dreams in understanding everyday behavior. What usually remains hidden (latent) in normal science becomes visible in science novels, although we must be aware of processes 
such as condensation ("Verdichtung"), displacement ("Verschiebung"), representability ("Vorstellbarkeit") and similar textual phenomena at work. Traditional psychoanalytic approaches tend to focus either on authors (their neurotic conflicts and unconscious desires) or on key characters (as if they were real patients, whose vicissitudes allow us to analyze hysterical or paranoid behavior in detail), but such "pathographical" approaches have been sufficiently discredited (Urban and Kudszus 1981; Wright 1984, Brooks 1987, Ellmann 1991). My focus will be on the texts as such, notably on a number of typical (repetitive, formulaic, symptomatic) scenes in which basic concerns, anxieties and expectations associated with emerging technoscience become tangible.

\section{Societal concerns: the disruptive impact of a "scientific crisis"}

1969 was a remarkable year for science. It was the year of the moon landing: a highly visible scientific event, but it was also the year in which ARPANET, the (military) precursor of the Internet, was launched: an electronic network allowing supercomputers at four universities in the USA to communicate and share data with one another. And it was the year in which Crichton published his first "science novel", The Andromeda Strain ([1969] 1993), about a lethal bacterial infection caused by satellites as "vectors". The opening sentence of Crichton's debut ${ }^{5}$ reads as follows:

This book recounts the five-day history of a major American scientific crisis. (3)

Subsequently, he adds that ...

This country supports the largest scientific establishment in the history of mankind. New discoveries are constantly being made, and many of these discoveries have important political or social overtones. In the near future, we can expect more crises ... Thus I believe it is useful for the public to be made aware of the way in which scientific crises arise, and are dealt with.

Subsequently, the meaning of the term "scientific crisis" is elaborated in more detail. These pages read like a manifesto in which the author explains the basic principles of his authorship, and the lines cited above may be seen as the opening lines, not of a single book, but of a whole oeuvre. The term "scientific crisis" (or simply: "crisis") remains important throughout Crichton's writings, recurring in almost all of his novels, thus functioning as a basic "signifier". Virtually all his novels purport to recount a scientific crisis, in one research area or another. In his "Introduction" to Jurassic Park, for instance, Crichton presents it as an account of a "genetic crisis" (1990, ix), unleashed by a private company called InGen. The term "scientific crisis" defines the way in which his books are structured. They are organized around this phrase.

The concept "scientific crisis" was first deployed by Husserl in 1935, in a gloomy exposé on The Crisis of European Sciences ([1935] 1977). Notwithstanding the obvious differences between the text by Husserl (dating from 1935) and the 
text by Crichton (dating from 1969), in terms of language (German versus American), length, style, idiom and the like, there are striking similarities as well. For both authors, the concept of "scientific crisis" entails a paradox, as crises are closely connected with major scientific breakthroughs, such as quantum physics or space travel. How can Husserl, and subsequently Crichton, earnestly claim that the modern sciences, with their breathtaking achievements, their "triumphs", their enormous prestige, are unleashing a profound crisis? For both Husserl and Crichton the term "crisis" does not pertain to the (often quite impressive) scientific achievements as such, but rather to their meaning for society: the potentially disruptive consequences for the human "life-world", as Husserl phrases it. Moreover, both authors contended that such a crisis usually has its (invisible) beginnings long before the dramatic (visible) onset actually occurs, so that, during the incubation period, only a limited number of individuals are aware of the looming threat. And then, suddenly, because of what (in Crichton's version) may seem to be a minor additional ingredient, the crisis suddenly explodes, surging to the surface, becoming acutely visible for the public, as well as for politicians and policy-makers at large.

Hence, for Husserl and Crichton there are two dimensions to scientific progress, a "manifest" dimension and a "latent" one. Whereas quantum physics was a new, intriguing development in the 1920 s, the latent (disruptive) dimension was there from the very beginning, but became suddenly visible when two nuclear bombs were dropped on Japan in August 1945. All of a sudden, the dreary meaning of Husserl's message (clad in fairly abstract terms) became painfully clear. Scientific progress apparently comes with a price. Due to quantum physics, the sway of humankind over matter and energy had dramatically increased. This latent dimension becomes acute as soon as the new knowledge spills over from the laboratory into social spheres where the collateral damage of promising breakthroughs suddenly unfolds. In Crichton's oeuvre, moreover, the focus of attention has shifted from physics to biology and the molecular life sciences. As Crichton phrases it, the next crisis will be a "biological crisis" (18). I will begin my analysis of Crichton's writings in medias res, with his mid-career novel (and peak performance) Jurassic Park, in which the idea of a scientific crisis is fleshed out in a paradigmatic manner. ${ }^{6}$ And I will focus particularly on how the novel addresses the gender dimension: notably the contrast between infantile phantasies of omnipotence enacted by male scientists, and the countervailing reality principle (sensitivity to complexity), represented by their female antagonists.

\section{Technophilia and technophobia in Jurassic Park}

Crichton's most famous novel is his genomics novel Jurassic Park (1990). The basic storyline is well known. Genomes of extinct Jurassic species (dinosaurs) are reconstructed from amber-encased DNA, allowing eccentric billionaire John Hammond to set up a tourist attraction in an environment as authentically 
"Jurassic" as possible: a tropical forest area on a Costa Rican island, where visitors may temporarily "leave the normal world behind" (83). This is achieved with the help of the genome, the long and winding thread connecting the Jurassic past with the anthropocentric present. DNA is "the most valuable material in the world" (69), the common denominator of all life, ${ }^{7}$ shared by all life forms, both inside and outside labs, regardless of their geological epoch. Before opening the amusement park to the public, however, a site visit is conducted by a team of experts consisting of Alan Grant (paleontologist), Ellie Sattler (paleobotanist) and Ian Malcolm (mathematician, interested in chaos theory). ${ }^{8}$

From a Freudian perspective, the idea of a secret island or Park builds on a typical childhood phantasy. Psychoanalytically speaking, Jurassic Park is a phantasy world, a playground where adults enjoy and enact their dreams (Kofman [1974] 1991, 6). As Freud ([1908] 1941) points out, (adult) daydreams contain elements of "regression" toward childhood reveries, and he explicitly compares these phantasy worlds with natural reserves or conservation parks ("Naturschutzparks", [1917] 1940). ${ }^{9}$ While the social world is overwhelmed by exacting reality, small clearings are singled out where repressed desires (whose fulfillment is denied to us in real life) can still be acted out, as a compensation for what we were forced to give up in adulthood. Much like Voyage to the Centre of the Earth by Jules Verne or The Lost World by Arthur Conan Doyle, Jurassic Park revivifies a wondrous bio-scape that otherwise has completely vanished.

This Freudian scenario is confirmed and enacted in Crichton's book. The Park is a high-tech bio-theater and the main characters were meant to be Hammond (a wealthy but childish entrepreneur who uses his dollars to live out personal juvenile phantasies) ${ }^{10}$ and his two grandchildren Alexis ("Lex") and Tim, who are granted the privilege of being the Park's first visitors, before it will be opened up to masses of children and their parents. The adults (Grant, Sattler, Malcolm) only become the key players of the book because things start to get completely out of hand (so that they quickly assume the role of surrogate parents): an intrusion of the reality principle, so to speak, destroying the phantasmagorical dinosaur habitat as if it was merely a dream, disrupted by a moment of awakening. ${ }^{11}$

Jurassic Park stages a regression, both in terms of biography (to childhood reveries of people such as Hammond) and in terms of geological time (to a bygone geological epoch). Ontogeny recapitulates phylogeny and the return of remote ancestors of current life forms concurs with the comeback of infantile phantasies in full splendor (as a temporary triumph of repressed imagination over the reality principle). The novel constitutes, as Freud phrases it, a "correction" ([1908] 1941, 216; [1909] 1941, 229) of a reality which refuses to satisfy our deepest desires, such as: spotting and meeting large (Jurassic) animals in their own habitat.

This reading is also confirmed by an instance of "wild analysis" (Freud [1910] 1943 ) in the book itself which involves paleontologist Alan Grant who (experiencing the privilege of observing live Jurassic specimen in the wild) explains the intense fascination of so many children for dinosaurs in psychodynamic terms: 
He finally decided that children liked dinosaurs because these giant creatures personified the uncontrollable force of looming authority. They were symbolic parents. Fascinating and frightening, like parents ... (Crichton 1990, 15)

From a psychoanalytic perspective, large animals remind us of (unconscious) images of adults / parents, instilled in us at a very early age. Name-giving (taxonomy) is then portrayed as a first effort to gain control over unknown, frightening nature:

Grant also suspected that was why even young children learned the names of dinosaurs ... Saying these complicated names was a way of exerting power over the giants, a way of being in control. (15)

An element of "sublimation" is involved as well, however, allowing both Hammond (the genomics entrepreneur) and Crichton (the science novelist) to reconnect childhood phantasies with the reality principle, that is: with current developments in the adult world, such as the rise of automated, high-tech research facilities and privatization of science. Hammond and Crichton sublimate their phantasy in profitable ways, and the imaginary Park becomes connected with prominent features of contemporary existence (such as computers, automated sequencing machines, biotech firms and global tourism), although in the end experts agree that the revivification of Jurassic species will prove unfeasible. ${ }^{12}$ Hence, Jurassic Park is, as Freud phrases it, a "compromise" ([1917] 1940,373 ) between reality and phantasy, between contemporary technoscience and (infantile) desire.

As the drama unfolds, it becomes clear that this compromise (between reality and phantasy) cannot hold. The basic flaw of the project resides in its deterministic premises: the idea that living creatures are their DNA and can be manipulated and contained with the help of DNA, by inducing specific mutations that make them dependent on human husbandry for their survival. ${ }^{13}$ Moreover, Jurassic Park is (allegedly) inhabited by female animals only, so that not only survival, but also reproduction is allegedly controllable by humans (by human males, to be exact). The designers not only failed to take into account that in the dinosaur world, females are bigger and more aggressive than males, but also that nature always "finds a way" (159): the dinosaurs solve their induced genetic deficiency and even manage to change their sex.

As a research facility, the park is dominated by high-throughput, automated sequencing machines, reading and reconstructing Jurassic genomes at ultra-fast speed, in assembly line fashion. These machines represent what Lacan refers to as the "symbolization" of the living. Life is reduced to a limited set of basic constituents (genes, nucleotides, etc.) that can be either present or absent, and can be represented by means of a concise set of symbols (A, C, G and T, for instance) that make it possible to re-arrange and reprogram the barcodes of life in infinite ways, granting humans beings (notably males, working in high-tech laboratories, behind computer screens) a seemingly all-encompassing technological power over nature 
(Zwart 2013). This reduction of living organisms to letters literally entails an "obliteration" of life as we know it, making it technologically reproducible on demand. Although Hammond wants his animals to be as "authentic" (true to life) as possible, they are nonetheless "numbered", "revised", "updated" and "released" as software packages (128), as bio-objects (Vermeulen, Tamminen, and Webster 2012), as oversized biotech pets.

As a theme park, Jurassic Park is dominated by the fascinating images of revivified, undead dinosaurs, browsing the tropical landscape, or devouring one another. This brings to life a basic imago or Gestalt: the dinosaur as the ultimate instantiation of the unsettling monster archetype (Zwart 2008, 239). In Lacanian terms: the imaginary realm of fascinating images, too alluring to be true. In the end, however, the system inevitably collapses and the resurrected diorama experiences its "second death". This represents (in Lacanian terms) the intrusion of the "real". The dinosaurs start to behave in unexpected ways and in the end, something rather disruptive happens.

Jurassic Park is basically structured as an experiment. Besides the main research question to be tested (can cloned Jurassic animals survive outdoors?), more specific issues of contemporary paleontology are addressed as the drama unfolds, such as: Are dinosaurs warm-blooded (Luck-Baker 1993)? How fast are they? Do they have paternal instincts and care for their offspring? Will they prefer solid ground over shallow water? Are they predators of scavengers? Are they clumsy and oversized, or graceful and dignified? ${ }^{14}$ The possibility of publishing the outcomes of this outdoors experiment in scientific journals is explicitly discussed (124). Yet, the Park facilities would be too expensive (203) to be used for research purposes only, so that tourism functions as a support activity, a source of funding. Laboratory trials are being brought into the open, where they become entangled with the complexities and un-predictabilities of the wider social world. In the end, "the experiment is a mess" (373) and needs to be abandoned before it really got off ground. Ian Malcolm had challenged the project's viability from the very start, and the validity of his arguments is reinforced by the severe leg injury that cripples him for life, ${ }^{15} \mathrm{a}$ scar that works as a reminder of a hazardous encounter with a big female dinosaur assailant.

As the man-made system breaks down, human chronic vulnerability is revealed. Technology has created an illusion of power over life, but as soon as the high-tech machinery falters, humans regress into a position of helplessness, becoming animals of prey, rather than managers in charge. Bereft of protective devices, humans suddenly become fragile again, unable to survive a full-fledged exposure to the threatening "real" (exemplified by voracious dinosaurs).

\section{The biotechnical reproducibility of undead life as a gender issue}

This dramatic shift (from control to vulnerability) mostly involves male laboratory scientists, such as chief geneticist Henry Wu. Initially, as a lab virtuoso, he seems 
completely in control. Wu manipulates dinosaur DNA "as a sculptor might clay or marble" (209). He basically regards life as a computer program:

Whatever problems might arise ... were essentially point-problems in the code, causing a specific problem in the phenotype: an enzyme that didn't switch on, or a protein that didn't fold. Whatever the difficulty, it was always solved with a relatively minor adjustment in the next version". (150)

Toward the end of the novel, however, his defenseless body is ripped to shreds by the claws and teeth of a (female) velociraptor. ${ }^{16} \mathrm{Wu}$ 's indifference toward the realities of dinosaur existence, once the animals leave the lab, contrasts with the more "feminine" sensitivities of Ellie Sattler, the paleobotanist who points out that life under real-life conditions (under the sway of the reality principle) is much more complex than imagined when the park was designed. Notably, animals are prone to suffer from the mismatch between Jurassic genomes and contemporary habitats and diets.

Indeed, as Ju (2008) argues, Jurassic Park is like a "crucible" where different types of scientists are tested until their true moral character is displayed (27). The outcomes reveal a close correlation between commercial interests and moral corruption, but also show that gender is an important factor determining adequacies or inadequacies of human responses.

Technology compensates for physical vulnerability, but extreme dependence on (unreliable) technologies inevitably becomes a concern it its own right. In the final pages of the book, the catastrophe is presented as only preventable by systematically destroying all Jurassic animals in a hail of explosions, as if evolution repeats itself and the fatal meteorite strikes once more. The great extinction of 66 billion years ago is re-enacted, purposefully, albeit on a smaller scale, so that the death drive (the will to destroy) finally gains ascendance over the desire to revivify extinct life forms. This scenario emerges as a crude "male" response while a more sensitive, less disruptive alternative might have been possible.

Thus, the issue of gender becomes increasingly foregrounded. In previous analyses such as by Freeland (1996), Franklin (2000) and Stern (2004), gender politics in Jurassic Park tends to be depicted as stereotypically biased and as "extremely conservative" (Stern 2004, 354), with John Hammond creating new, un-mothered forms of life in order to outclass and subdue the feminine other (the feminine monster), whose body male scientists want to meet, touch and see despite the dangers involved in such voyeuristic pleasures, while commercialization is framed as a menace to traditional (male-controlled) research. In this paper I will argue that, on closer inspection, Crichton's portrayal of gender relations is actually much more destabilizing. In Jurassic Park as a filmic, evolutionary diorama, enacted in an ecological theater, staging the transient moment of interface between the Age of Dinosaurs and the Age of Man (Haraway 1989, 26, 535), a somewhat different, less predictable scenario unfolds. While the males themselves are responsible for creating the mayhem (bent as they are on turning nature/ 
genomes into resources for commercial appropriation), the female dinosaurs, as well as the female scientists studying them, increasingly step forward as the key actors, overtaking the initiative to restore some level of equilibrium in the chaotic mess resulting from the masculine misconception that life can be made manageable, controllable, modifiable and commodifiable with the help of hightech science. In the next section, I will further develop my analysis with reference to Crichton's novel Congo, published a decade earlier (in 1980).

\section{Technology dependence and the "object a"}

Congo also addresses a topical societal issue, namely the similarity between humans and (other) primates, represented by a female gorilla named Amy, raised in an animal research facility at Berkeley and fluent in gestural sign language. Comparative genomics and cross-species communication (via sign language) are making us more aware of inter-species congeniality:

The degree of similarity [between chimpanzees and humans] was not fully known until 1975, when biochemists compared the DNA of chimps and men. It was discovered that chimps differed from men by only 1 percent of their DNA strands. (276)

Comparative analysis of the genome sequences of Homo sapiens (finished in 2004) and chimpanzee (finished in 2005) has strengthened this awareness. ${ }^{17}$

As in Jurassic Park, a further issue is explored as well - the tension between insights gained from research conducted in university laboratory settings and the complexities of the world beyond the lab. This is exemplified by phrases such as the following:

[Scientists] worked all day in laboratories where conditions could be rigorously regulated and monitored. Sooner or later, scientists came to believe that the outside world was just as controllable as their laboratories ... the shock of discovering that the natural world followed its own rules and was indifferent to them represented a hard psychic blow. (150)

In Congo (1980), the frightening, terrifying "real" is represented, not by a revivified Jurassic world, but by the Central African rain forest, depicted as a gigantic silent environment with enormous trees: a vast, oversized, alien place, inhospitable to humans (3). A tiny human enclave comes into view, a technological clearing: an expedition campsite; connected by means of an electronic "umbilical cord" to the civilized world, consisting of a silver dish antenna, a black transmitter box, coaxial cables and a portable video camera. Indeed, Crichton tells us that "the Americans use this equipment to transmit daily reports by satellite to their home office in Houston" (4), a comment which underscores the affinity between this expedition (into the heart of Africa) and the Apollo moon landing. But then there is the intrusion of the real. All members of the team are killed within seconds, and the electronic connection is disrupted. 
This dramatic event is described in a rather uncanny way. Skulls are crushed and eyeballs ("pinkish white with a shred of white optic nerve still attached at the back", 7) are severed. A few hours later, in Houston, Karen Ross, a "mathematical prodigy" (12), six feet tall, is sitting behind a computer terminal in an office packed with high-tech equipment. A satellite transmission displays an overview of the demolished camp site, with its mutilated corpses. Just before the breakdown of the system, the silhouette of a gigantic gorilla comes into view, the local version of the monster archetype. ${ }^{18}$

In one of his seminars, Lacan spoke about the Apollo project and space travel. The astronauts, he argues, traveling far beyond the field of gravity of planet earth, remain within the "alethosphere", the realm of techno-scientific discovery, opened up by modern communication technologies $(1991,187)$. During their journey through space, they are accompanied by the electronic version of a human voice: their auditory connection with Houston. As long as this connection is alive, they still cling unto this alethosphere, the realm of electronic communication (188).

Lacan refers to such a device as an object $a$. It is basically an "organon", an appendix, an electronic umbilical cord, that can be either present or absent, and is detachable to some extent, but connects us with a life-saving Other (in this case: "Houston"). This not only applies to space travel, but to human existence as such. After birth, during the "oral stage", Lacan argues, the breast of the mother, notably the nipple, functions as our object $a$. The life-saving "partial organ" belongs to the mother's body, but seems to stand apart, to some extent. This is underscored by the possible use of artificial substitutes such as comforters: the "partial" object seems replaceable more or less. But the object a may also refer to the human gaze (with the eyeball as its carrier) or to the human voice (and its electronic transmitters).

If we read Crichton's scene from a Lacanian perspective, the members of the expedition are suddenly and drastically bereft of their vital "organ(on)", their object $a$, on various levels. First of all, they are bereft of their equipment (communication technology, the electronic voice, the silver dish antenna as a "gaze transmitter"), but also of their eyeballs. The scene amounts to what, in Freudian argot, can be referred to as an emasculation scene (although the mutilation shifts from testicles to congruent body parts and their electronic substitutes). Without their contrivances, the male inhabitants of the campsite all of a sudden experience their extreme fragility. During the process of hominization, the hominid male body had become "feminized", that is, deprived of its built-in, biological weaponry such as large canines and claws, resulting in increased dependency on artificial equipment (Haraway 1989, 209). Now they are completely overwhelmed and silenced in every way, and swallowed by the jungle (by armies of flies and insects, consuming their corpses in no time, representing the devastating real).

The novel's heroine is Karen Ross. Seeing the devastation, the "crisis" (18) that has occurred, she immediately decides to lead the return expedition team of Earth 
Resources Technology Services (ERTS, the organization for which she works) into the wild. And she invites Peter Elliot from Berkeley, a primate expert who, among other things, studies "dream behavior"19 in Amy, to join her team. As the craft of training simians (such as Washou, Koko and Lucy) to communicate through American Sign Language (AMESLAN) had become a niche for female scientists, employed at Berkeley and other Western universities, alternating laboratory trials in Silicon Valley with field work in the African jungle (Haraway 1989), Elliot's intense relationship with Amy (combining daily scientific observations with friendship) already represents an instance of gender role reversal. Their liaison is quite reminiscent of the "emotional drama" that evolved between Janis Carter and her favorite primate Lucy as described by Haraway (1989, 131). Like in Lucy's case, moreover, Peter Elliot's project culminates in a rehabilitation experiment, as he grasps the opportunity provided by Karen Ross's invitation to encourage Amy to "return" to the wild, so as to converse with her still primitive congeners on site.

Karen's ability to take the lead not only derives from her physical traits (in view of her height and strength she is referred to as a "virile Texan woman", 61) but even more so from her impressive technical and managerial capabilities:

[Elliot had assumed that Karen Ross was] an academic like himself. But [their] enormous airplane filled with computerized equipment, the acronymic complexity of the entire operation suggested that Earth Resources Technology had powerful resources behind it. (78)

In fact, Congo is designed as a personality test to assess her leadership qualities, comparing personality test results (a "psychograph" taken of Ross as an ERTS employee, 29) with her performance as the tale unfolds. ${ }^{20}$ Ironically, the more "masculine" aspects of her personality profile ("domineering", "insensitive", "single-minded", "driven to succeed at all costs", etc., 334) become her fatal flaws (albeit under highly unusual circumstances: a volcanic eruption, instilling in her a "perverse" desire to stay and watch the unique phenomenon instead of simply running for her life, 331). While in the beginning of the novel the allmale team was involuntarily bereft of their transmission equipment by aggressive apes, Karen demonstrates her independence by willfully ignoring the incoming instructions from Houston and by turning the transmitter off, in order to witness the unique events undisturbed (317).

This division of roles on the basis of gender - between Karen Ross as the dominant, worldly, active female on the one hand and Peter Elliot as the submissive, ${ }^{21}$ unworldly, laboratory-dwelling male (and as a replacement for the overpowered, dismembered male crew members) on the other - represents a basic structural element throughout Crichton's writings. It all begins with male-dominated science, represented (for instance) by Henry $\mathrm{Wu}$, whose illusory experience of being completely in control is erroneously extrapolated into the outdoors world of complex reality, so that a crisis is inevitable. Outside the laboratory, only 
female researchers seem to have sufficient stamina and sensitivity ${ }^{22}$ to come to terms with the crisis thus produced - although in some of the novels, including Congo, the traditional gender balance is restored in the end: during the grand finale, when the female lead is overdoing it (becoming too "masculine" as it were - that is, too ambitious, arrogant and dominating). In Crichton's writings, research strategies (reductionism versus complexity) become entangled with the topological dimension (indoors versus outdoors) of the novel as well as with gender relations (and polarized features associated with it, such as strength versus weakness, activity versus passivity, sensitivity versus egocentricity, etc.). This connection between the (reversed) gender dimension and laboratory science will be explored in more detail in the next two sections.

\section{The gender dimension and outdoors science}

I will start with some passages taken from Crichton's books, addressing gender relationships in ways that are highly typical of his oeuvre. The first scene is taken from The Lost World (2002), Crichton's sequel to Jurassic Park, set on a tropical island off the Costa Rican coast. Ian Malcolm's crippled leg is a painful reminder of his encounter with the ("big female") tyrannosaurus. ${ }^{23}$ Nonetheless, he is still interested in everything pertaining to Jurassic extinction and survival. His female counterpart is Sarah Harding, a young, athletic, muscular, female ethologist from San Diego, a heroine and role model for young girls with a penchant for science (61), who spent many years in Africa studying large predators in the wild:

Malcolm hobbled across the open courtyard of the Institute. Walking beside him was Sarah Harding ... They made an unlikely pair: Malcolm stooped and ascetic; Harding compact and muscular, looking young and energetic. (7)

Elsewhere, she is described as "beautiful and independent" (61), living the life of a scientist in the field, alone in Africa, "famously tough" (62).

At a certain point in the novel, this "unlikely pair" (Harding-Malcolm) is attacked by two large tyrannosaurs, one of them a "big female" (284). The frightening reptiles push two trailers off a cliff, whereupon Sarah manages to rescue two male colleagues, Ian Malcolm among them, by first climbing out of the trailer herself and then "dragging", "carrying" and "hauling" her male colleagues out as well. While rescuing Malcolm, the following dialog evolves:

"Ian, we have to get out of here." She grabbed him under his armpits and pulled him upright. "And you're coming with me." He shook his head, defeated. She hated to see it. Harding never gave up ... Hanging behind her, Malcolm wheezed; his arms around her neck were trembling. He said, "You're very strong." "But still feminine," she said, grimly. (301)

Another male colleague is rescued by Harding in a similar way: "She was immensely strong" $(304){ }^{24}$ 
The next scene is taken from Prey (Crichton 2002). At the start of the novel, we find male protagonist Jack (a former computer scientist) at home (while his wife Julia is making a stellar career in a nanorobotics company named Xymos), giving voice to his discontent:

I never intended to become a househusband. Stay-at-home husband. Full-time dad, whatever you call it - but that's what I had become. (5)

Almost 500 pages and many thrilling adventures later, when they meet for the very last time, the following dialog evolves:

"Jack. Please. Let's put emotion aside and be logical for a moment. Why can't you accept the new situation?" She held out her hand to me. I took it, and she pulled me up. She was strong. Stronger than I ever remembered her being ... I sighed. I was feeling distinctly weak in her arms. ${ }^{25}(466,467)$

The third and final scene is taken from the novel State of Fear (Crichton 2004). Its first chapter is set in Paris, where Marshall, a young physicist (who simulates tsunamis in his solitary lab) receives a visit from Marisa, a mysterious young woman, involved in an international terrorist organization. Quickly bored by Marshall's demonstration of laboratory equipment, Marisa suddenly moves into action:

Unceremoniously, she pulled her top over her head and dropped her shirt ... Still in her high heels, she walked toward him ... "I told you: I do not like to wait," and threw her arms around him and kissed him hard, fiercely, almost angrily ... she never spoke. She was so passionate she seemed almost angry, and her beauty ... intimidated him. (12)

After Marisa has left him all alone in the room, Marshall is taken by surprise and forced into a completely passive position by three male intruders:

With a bang! The door slammed open and three men burst into the bedroom. He yelled in alarm and panic as they threw him over, shoving him facedown on the bed ... they pushed his face into a pillow ... One man was sitting on his back, knees digging into his spine... The other men had each taken one of his wrists, and they were pulling his arms wide, spread-eagling him on the bed. They were getting ready to do something to him. He felt terrified and vulnerable ... (13)

Instead of downright violating him, however, they press something under his armpit, something "sticky", whereupon he feels a "little pinch, hardly noticeable, a momentary sting". Upon Marisa's return, she single-handedly manages to chase the visitors away, and they go for a stroll along the Seine, but soon Marshall begins to feel dizzy, "oddly weak": a kind of "clumsy weakness" courses through his body, and he realizes that he is becoming completely paralyzed (as a result of the sting):

She ducked her head under his arm and with surprising strength got him to his feet. His body was loose and floppy ... she continued on her way, carrying him ... he was completely paralysed. He could do nothing. His own feet were scraping over the stone. Toward the river. "I am sorry," she said, and she dropped him into the water. (16) 
These three scenes present variations on a typical Crichton theme, of which more examples could be given. It is, in Freudian terms, a "symptomatic" phantasy, pervading the author's oeuvre. Such scenes can be encountered, one way or another, in all of Crichton's books, involving a male protagonist, who is initially presented as autonomous and masculine, finding himself outclassed and overpowered by a female personage. The latter combines beauty and intelligence with stamina and strength, and proves able to deal effectively with the most terrifying foes (whether criminals or large animals). The masculine hero seems to faint, to effeminate, in her powerful embrace. Perhaps the most famous/notorious example is the harassment scene in Disclosure (1994), involving Tom Sanders (a computer expert) and Meredith Johnson (his recently appointed boss), who intimidates, teases, straddles, pins, bites, scratches and threatens him in her office ("she grabbed him fiercely, smiling a victorious smile... She had won" (94), although some critics argue that such role reversals may rather function as denial ("Verneinung"), obfuscating rather than addressing gender-based sexual harassment at work (Morrison 1994).

How to explain the ubiquitous presence of this (formulaic) scenario in Crichton's science novels? ${ }^{26}$ One could argue that we are simply confronted with a (rather obvious and well-tried) narrative device, namely gender role reversal, which adds suspense and drama to the situation. Seen from this perspective, a mere reversal of roles will not suffice to challenge traditional gender stereotypes as such. Quite the contrary: they may rather be reinforced by such a device (also because, in some cases, the role reversal is only temporary, so that the original "gender equilibrium" is restored - to the benefit of the male protagonist - in the end). And yet, I will argue, something more seems to be at stake here. From a psychoanalytic perspective, the typical phantasy definitely is a symptom. The question is, of what?

One possible answer is that it is part of the overarching crisis theme. Traditional "researcher-driven" research is dominated by male researchers, bent on controlling nature in their labs, relying on their know-how, their "hard" technical (manipulative) skills. The new research fields described in Crichton's novels, however, are different. They involve outdoors research practices (i.e. field work) and a significant amount of large-scale, interdisciplinary team work. The new situation tends to favor what could be regarded as "feminine" talents, such as sensitivity toward the behavioral needs of animals in the wild, or the so-called softer managerial and communicative skills required for functioning effectively in large-scale organizations. In Crichton's novels, science is continuously leaving the traditional laboratory, where lone, male, unworldly scientists once felt at home - felt "in control" - and is now entering the real word, either in the form of the great outdoors, or in the form of powerful companies and big research consortia - all of them quite threatening, apparently, for male scientific heroes of the old stamp. In these new environments, while finding themselves bereft of the laboratory equipment on which their sense of control (over nature, but also over female colleagues) 
relied, these male researchers are now defeated and outcompeted by women. The future of science belongs to the latter. ${ }^{27}$

Crichton's female characters tend to use their beauty, intelligence, endurance and sensitivity, their fine-grained technical dexterity and ability to focus, but also their physical prowess if needs be, to achieve supremacy in the ambitious, tricky projects the novels describe. The pendulum of gender relationships has swung in the opposite direction, so that, rather than accepting gender equality, males are now quickly losing ground in Crichton's high-tech version of the "battle of the sexes". They are becoming the weaker sex.

This "gender crisis" is closely connected, moreover, with the emasculation complex $^{28}$ discussed in the previous section, but also with developments within contemporary technoscience as such. The small-scale laboratory as the paradigm of science, where, for instance, faked miniature tsunamis can be safely analyzed and controlled, or where "living nature" can be subdued, made manageable, with the help of test tubes and other lab contrivances, is explicitly depicted as something of the past. ${ }^{29}$ It is dissolving into the large-scale, computer-based research networks of a quickly expanding scientific world. ${ }^{30}$

And this mélange of concerns converges into the three scenes described above. In the first one, Ian Malcolm is not only hampered by his damaged leg, but also by his unwise decision to leave his highly specialized, but fairly serene Santa Fe Institute for complexity research, ${ }^{31}$ so that he is now facing, not only deadly tyrannosaurs, but also a superbly trained female antagonist, bare-handedly as it were, in the open. Under such circumstances, even Malcolm (the male hero of Jurassic Park) finds himself emasculated, failing the test (with his aching leg symbolizing his faltering masculinity). A similar fate befalls co-scientist Richard Levine, a presumptuous paleontologist with an air of "scholarly absorption" (17) who, toward the end of the novel, with the dinosaur predators closing in, is presented as having no other choice than to sulkily obey the orders which "musclebound naturalist" Sarah Harding "barks" at him (353).

In the second scene (Prey) we witness Jack becoming increasingly passive as a consequence of his being disconnected from his computer science lab. But as soon as he is re-introduced into a lab-like environment once again (the Xymos facility where Julia became infected with the swarm) his testosterone level suddenly seems to rise, and he is able to resume his role as male Hollywood-type hero (while Julia's intimidating strength proves only imaginary: she is an undead, under the spell of the vampire-like swarm).

In the final scene (State offear) Marshall is able to play a stereotypical masculine role as long as he stays inside the protective laboratory walls, where he can control "tsunamis" at will. As soon as he is lured out of his secret bunker to follow the mysterious lady into her apartment, he enters a spider's nest. Here he is completely helpless, and stung with a paralyzing emasculating fluid. It is an emasculation experience, but displaced ("verschoben") by a sudden failure of muscular strength as a secondary sex characteristic - a case of metonymy so to speak. 


\section{Gender in Crichton's final novel}

A similar case of gender role reversal dominates Crichton's final, posthumous novel Micro, co-authored (finished) by Richard Preston. A wealthy techno-entrepreneur (President of a mysterious research company called Nanigen) manages to lure an interdisciplinary team of young Ph.D. students out of their university laboratory and into the Hawaiian jungle, where they are subjected to a perverse experiment, causing them to shrink into minute-sized creatures (about half an inch tall) so that they wander aimlessly through the microworld of plants and insects as edible, ill-adapted and unprotected packages of protein, but also as living magnifying glasses: the visual, auditory and olfactory sense organs of the author, allowing him to paint a vivid picture of life in the undergrowth, among mites, ants, spiders, beetles, centipedes and nematode worms.

One by one, they fall victim to this violent Eden, where scent and sound constitute the lingua franca of living things. Of a group of seven, only two young researchers manage to survive: Karen King (an arachnologist or spider expert) and Rick Hutter (an ethnobotanist, interested in indigenous medicine). Their division of labor reflects the reversal theme described above. While Rick carries the food supply, Karen proudly waves her improvised machete.

Their most dramatic encounter involves a monstrous, female solitary wasp. ${ }^{32}$ As soon as the wasp spots Rick, she comes for him, straddles him, pins him between her mandibles and brings forward her sting, paralyzing him with her venom. ${ }^{33}$ Then, she grabs him between her legs and carries him off into her nest, to feed her grub. While being deposited on the floor, Rick wonders whether the hungry grub will "bite off his genitals first" (398), but Karen comes to his rescue just in time. In the duel that unfolds, Karen (a scientifically schooled gladiatrix) manages to decapitate the wasp. Then, stronger than ever ("strong as an ant", because of her miniature size), she hoists Rick over her shoulder, drags him out of the nest and drops him in the sand under the shade of a plant.

Thus, all the elements of the "typical" scene (as outlined above) are present once again, but now in a rather unrestrained (unmasked, uncurbed, even childish) way: the role reversal phantasy acted out in its purest form. In this portrayal, women outcompete men in every imaginable way, as soon as they leave the lab (a setting apparently designed for postponing the gradual but inevitable loss of male control in science). The Hawaiian jungle is the phantasy world where childhood reveries (involving different gender roles than in adult society) can be enacted. When Karen and Rick are finally restored to normal size again, they are plagued by an unsettling unease: the desire to return to their fascinating micro-Eden. Apparently, their exposure to role reversal adds to their nostalgia. According to Lacan, however, Eden is an imaginary world par excellence, where desire becomes incarnated in archetypal images that provide illusory fulfillment only. But the transition processes in science (the processes of technological and institutional transformation depicted in Crichton's novels) are real enough, redefining not only research 
methodologies, but also gender relationships in irreversible ways. The implication seems to be that, from here, the new standard of female supremacy may spread to society at large.

These typical scenes are a compromise between phantasy and reality, a temporary correction of the latter, as we have seen (Freud [1917] 1940). The Hawaiian jungle offers an escape from frustrating reality, so that childhood memories may revive. The students are miniaturized to begin with. Nature is perceived through children's eyes, even to the point of exaggeration. They wander through the forest like tiny toddlers who, for the very first time, have fled from parental surveillance. These "parents" (big bad adults ${ }^{34}$ running the research facility) keep looking for them, but they desperately try to stay out of their hands. Wasps and other (usually female) predators play a role comparable to the velociraptors and other carnivores in Jurassic Park. The researchers are like seven highly trained Tom Thumbs, desperately testing scientific knowledge in unknown situations.

As soon as "pure" researchers leave the lab and enter the real world, they feel shrunken, awkward and orphaned. The laboratory emerges as a safe haven which keeps the outside world at bay, where processes are made predictable and simple, safeguarded from chaotic and disruptive factors, and where researchers can "play" with their equipment. In the outside world, notably the male scientific ego feels estranged and helpless, emasculated and handicapped, whereas female researchers rather seem to benefit from it. This explains why the male characters are so reluctant to enter the outside world, to leave the protected lab space where they are seemingly in control (immunized against reality). The typical scenes confirm the validity of their reluctance. Outside the lab, the rules of the game will change.

Thus, the typical scene is a (phobic) symptom. The "ego" (male protagonist) of a typical Crichton novel prefers the experience of illusory control, provided by hightech research. And yet, he is drawn into the unpredictable, toward adventure, finding himself outclassed by well-trained women. Hazardous encounters take place with entities inhabiting this extramural space (female researchers, but also large animals, commercial firms and extraterrestrial life forms): challenging experiences from which the male ego barely manages to escape. Crichton's novels describe experiments (disconcerting to some, fascinating to others), not only with the "technologies of the future," but also with the shifted gender relationships they entail.

The question then is whether these are merely temporary theaters of destabilization, role reversal and change, or rather symptoms signaling an ongoing, relentless, large-scale transition. On the manifest level, Crichton the author tends to evade this question. We are only briefly informed about what happens once the dust has settled down. As a rule, all participants (both male and female) seem to lose something of value in the end (their jobs, their lives, their dreams). Yet, even those novels which suggest a return to "normal" (indoors, laboratory) science as a "happy end" 
(restoring traditional technology-dependent male dominance) convey the expectation that similar collisions are bound to follow, and that the drift toward hypermodern styles of doing research, including a drastic revision of gender roles (now temporarily halted), will prove inescapable in the long run. This for me is a key motif of Crichton's oeuvre. As far as the manifest plots of separate novels are concerned, however, it tends to remain an open-ended question: what happens next is left to the imagination of the reader.

\section{Acknowledgements}

This paper presents research conducted in the context of the Centre for Society and the Life Sciences and builds on a series of lectures presented at various conferences, starting with "Genomics \& Imagination: Public responses to transformations in knowledge production" (Cesagen Conference, London, Royal Academy of Sciences, 2 March 2004), but also on the annual master course Science and Literature mentioned in the Introduction. Finally, I am indebted to the two anonymous reviewers for their constructive comments, careful reading and detailed suggestions.

\section{Disclosure statement}

No potential conflict of interest was reported by the author.

\section{Funding}

This research was funded by NGI (the Netherlands Genomics Initiative).

\section{Notes}

1. The term "science novel" is used here as a provisional label for an emerging, loosely defined genre of fiction also known as "lab lit." Unlike science fiction, it presents (semi-realistic) portrayals of contemporary scientists and the (usually high-tech) research practices they are involved in (Rohn [2006] and Mawer [2005]). Depending on the amount of drama and suspense, they may also be listed as "techno-thrillers."

2. Although genomics (the research field that uses automated, high-throughput DNA sequencing for studying genomes) plays a role in several of his novels, Crichton's most prominent "genomics novels" are Jurassic Park, The Lost World and Next.

3. This issue is addressed by Crichton as well, namely in Sphere, the novel which deals most extensively with psychology:

Norman's research [on anxiety] was considered brilliant, but psychology was notoriously prone to intellectual fashions and interest in the study of anxiety was declining, as many researchers came to regard anxiety as a purely biochemical disorder ... Norman himself could not comprehend this ... He did not think that anxiety was going to be solved with pills. It seemed to him that a society in which the most common prescription drug was Valium was, by definition, a society with unsolved problems. ([1987] 1988, 13, 14)

The biochemical approach is portrayed as a "displacement" (15), a pretext to focus on surrogate challenges rather than facing the "immense problems" which Western societies fail to solve.

4. Psychoanalysis tends to have a preference for "lowbrow" (popular) over "highbrow" (elitist) literature: "[Wir] suchen für unsere Vergleichung nicht gerade jene Dichter aus, die von der 
Kritik am höchsten geschätzt werden, sondern die anspruchsloseren Erzähler von Romanen, Novellen und Geschichten, die dafür die zahlreichsten und eifrigsten Leser und Leserinnen finden" (Freud [1908] 1941, 219).

5. During the early stage of his career, Crichton also published a series of paperback novels under the pseudonyms John Lange and Jeffry Hudson. Although usually not included in the Crichton "canon," most of these novels are recognizably Crichton-like. Drug of Choice, for instance, published in 1970 (almost simultaneously with The Andromeda Strain), likewise opens with the crisis-theme: "The beginning of modern science is also the beginning of calamity" (7).

6. Jurassic Park (1990), written and published when Crichton was in his 40s, constitutes the midway point between his first science novel (The Andromeda Strain, 1969) and his final (posthumous) one (Micro, [2011] 2012).

7.

Most DNA in living creatures was almost the same. DNA was an incredibly ancient substance ... The DNA molecule was so old that its evolution had essentially finished more than two billion years ago ... This innate conservatism of DNA emboldened Wu [the Park's geneticist] to use whatever DNA he wished. (Crichton 1990, 209)

8. The fourth member (Donald Gennaro) is a lawyer and general counselor for InGen. In the movie he is eaten, but he survives in the novel, where he explains the purpose of the site visit as follows:

This is an island in which genetically engineered dinosaurs have been allowed to move in a natural park-like setting, forming a tourist attraction. The attraction isn't open to tourists yet, but it will be in a year. Now, my question for you is a simple one. Is this island safe? Is it safely containing the dinosaurs? (Crichton 1990, 88)

9.

Die Schöpfung des seelischen Reiches der Phantasie findet ein volles Gegenstück in der Einrichtung von "Schonungen," "Naturschutzparks" dort, wo die Anforderungen des Ackerbaus, des Verkehres und der Industrie das ursprüngliche Gesicht der Erde rasch bis zur Unkenntlichkeit zu verändern drohen. Der Naturschutzpark erhält diesen alten Zustand, welchen man sonst überall mit Bedauern der Notwendigkeit geopfert hat. Alles darf darin wuchern und wachsen, wie es will, auch das Nutzlose, selbst das Schädliche. Eine solche dem Realitätsprinzip entzogene Schonung ist auch das seelische Reich der Phantasie. (387)

10. This is how John Hammond is introduced in the novel: "There was a childlike quality to the man, even though Hammond must now be ... what? Seventy-five? Seventy-six?" (Crichton 1990, 59). Before setting up Jurassic Park, he had been involved in "consumer biologicals," selling miniaturized animals as toys or pets.

11. Topologically speaking, the resort is a utopian clearing, where "impossible" phantasies are temporarily given the floor. An early Crichton novel entitled Drug of Choice ([1970] 2013) is structured in a similar way. It is a story about a "fabulous," imaginary resort called Eden Island where a recently designed drug makes phantasies come alive in a dream-like fashion: "It's a resort ... a brand new resort of a type previously unknown. We're in the middle of an age, you know. The resort age" (82). The male hero is allowed to play tennis with a dauntingly beautiful female celebrity, "a blood player, a true fighter," by whom he is "miserably beaten" (114).

12. In contrast, perhaps, to the revivification of Pleistocene species, such as the woolly mammoth, which is now seriously being considered (cf. Church and Regis 2012). For a scientific 
assessment of the novel, from the point of view of the "reality principle," see DeSalle and Lindley (1997). As Stern rightly points out, however, although these authors send out a warning against Crichton's/Spielberg's popularization of science, their book is at the same time surreptitiously fascinated by (and draws its existence from) the butt of its scientific criticism, allowing them to "sell" their science $(2004,362)$.

13. Notably, their genome was modified so as to disable them to manufacture the amino-acid lysine, which had to be administered in tablet form by human caretakers.

14.

Grant was looking at something he had never expected to see in his life ... He began to laugh ... He had seen the animal for only a few seconds, but he had already begun to use his observations to answer long-standing questions in the field... (Crichton 1990, 80)

"Grant was struck by the coordination of their behaviour ... A skeleton was a poor thing, really, from which to try and deduce the total behaviour of an organism" (Crichton 1990, 394).

15. In Jurassic Park, it is suggested that Malcolm dies. In The Lost World, however, he is revivified, together with the dinosaurs. Crichton apparently needs him once more as a "critical reviewer" of revivification projects.

16. A similar scheme can be discerned in The Lost World ([1995] 2002), where paleontologist Richard Levine, despite his reliance on the latest animal-control technologies, quickly loses control over the situation when things get rough:

Suddenly, the forest erupted in frightening animal roars all around him. He glimpsed a large animal charging him ... and he realised in that moment that despite all his planning, despite all his clever deductions, things had gone terribly wrong, and he was about to die. (44)

17. This issue is taken up in 2006 in Crichton's genomics novel Next: "When the human genome was decoded, scientists discovered that the genome of a chimpanzee was nearly identical to that of a man. All that separates our two species is five hundred genes" (Crichton 2006, 192).

18. "[She] had a final glimpse of a large face and a dark hand as the silver dish antenna was smashed. The image from the Congo shrank to a spot and was gone" (17).

19. From Peter Elliot's perspective, Congo is the account of his experiments with Amy (the young female gorilla), his research subject $(N=1)$ of choice. How will she respond to the "call of the wild"? Will it stir her "genetic memory" (45)? The focus is on her dream behavior. After returning to Berkeley, Elliot even reverts to Freud's The Interpretation of Dreams (allegedly "published in 1887," 257) to make sense of his (inconclusive) results.

20. The issue of whether she eventually fails or endures the test may be a matter of interpretation. Strictly speaking, she fails, and in the epilog it is stated that she decided to abstain from doing fieldwork. Still, Trembley's (highly critical) assessment of her performance seems too negative (1996, 115-116).

21. He is submissive toward both his female partners in the novel, not only toward Ross, but also toward Amy, who physically abuses and "punishes" him whenever she gets angry (51).

22. In Jurassic Park, this role is played by Ellie Sattler.

23. In psychoanalytic terms, the leg injury becomes a metonymy of castration (a "Verschiebung" from phallus to thigh), as the encounter has irreversibly weakened him.

24. Brawny female scientists can be encountered in many Crichton novels, for instance, in Sphere ([1987] 1988), where zoologist Beth Halpern is described as "a tall, angular woman" with an "almost masculine" body (22), a "serious weight lifter and runner; the veins and muscles bulged at her neck and on her forearms, and her legs, beneath her shorts, were powerful" 


\section{H.A.E. (Hub) Zwart}

(22). Sphere is a genomics novel in its own right: scientists are offered a chance to compare terrestrial, genome-based life with extraterrestrial life forms. As Beth explains:

Everything we know about life comes from studying life on our own planet. But all life on our planet is the same. Every living creature, from algae to human beings, is basically built on the same plan, from the same DNA. Now we have a chance to contact life that is entirely different, different in every way. (23)

To do this, however, "rugged [male] individualism" must give way to teamwork, meetings and group decisions: a more "feminine" approach (13).

25. Toward the end of the novel, however, the traditional gender equilibrium is restored, with Jack once again assuming a masculine, heroic role, while Julia's prowess proves a temporary side effect or her infection by the nano-swarm. She strides through the laboratory, not as an autonomous person, but as a nano-vampire, a nano-undead, a Lucy Westra of the nano-age.

26. Crichton's autobiographical Travels ([1988] 2003) contains an account (entitled They) of experiences with "sex role reversal" $(288,290)$ in the 1980 s, describing "masculine" women (293) as "feminine machos" (289), taking up "traditional forms of male behavior," treating "powerless" men (294) as mere "sex objects" (288). Women, it is claimed, are "stronger, tougher, more interested in money, more preoccupied with work," while men are "weaker, more romantic, living out a phantasy" (290).

27. Read in this manner, Crichton's novels outline a scenario similar to the one depicted by Donna Haraway in Primate Visions (1989), where male researchers such as Robert Yerkes and Harry Harlow, who aimed to control and reengineer primates in their labs (as pilot plants for social engineering), are replaced by new generations of female researchers who develop more direct, interactive, empathic and dialogical ways of working with simians.

28. Another Crichton character that can be added to this list of "challenged" males is John Wright, the multitalented villain in an early novel entitled Binary:

What can a person do in the twentieth century? Each and every one of us is powerless in the face of giant corporations, giant institutions, giant government ... Everyone is locked into a system and is powerless to change. We are all trapped. ([1972] 2013, 42)

His revenge, a resourceful high-tech assault, can be prevented just in time.

29. See, for instance, one of Malcolm's exhortations in Jurassic Park:

Science is starting not to fit the world any more ... Science explicitly offered us the vision of total control... claimed the power to eventually control everything. But in the twentieth century that dream has been shattered beyond repair. And so the grand vision of science - the dream of total control - has died ... We are witnessing the end of the scientific era. $(312 / 313)$

30. Crichton gives voice to anxieties concerning the growing scale of research on various occasions, for instance, in Jurassic Park:

America entered the atomic age through the work of a single research institution, at Los Alamos. It entered the computer age through the efforts of about a dozen companies. But biotechnology research is now carried out in more than two thousand laboratories in America alone. Five hundred corporations spend five billion dollars a year on this technology ... Research in molecular biology has become a vast, multibillion-dollar commercial undertaking. (1990, vii/viii) 
See also Malcolm's Jeremiad toward the end of The Lost World, where he argues that "Cyberspace means the end of our species ... the end of innovation ... Mass media swamp diversity ... All differences vanish ... People worry about losing species diversity, but what about intellectual diversity - our most necessary resource?" ([1995] 2002, 311).

31. In Jurassic Park it is said that Malcolm "broke with the cloistered tradition of mathematics," hoping that his field could describe "something that actually existed in the real world" $(1990,72)$.

32. "She was a predator [with] nine brains [and] mated once with her husband, who dropped dead after having sex with her. She was a queen" (387).

33. "The sting happened very fast. Two stingers inside a sheath emerged. As the sheath drilled into Rick just under his armpit, the stingers lanced into him" (389).

34. The parental couple consists of Vin Drake, CEO of Nanigen, and its CFO Alyson Bender, who assassinates the brother of one of the students, but is liquidated herself by Drake.

\section{References}

Brooks, P. 1987. "The Idea of a Psychoanalytic Literary Criticism.” In Discourse in Psychoanalysis and Literature, edited by S. Rimmon-Kenan, 1-18. London: Methuen.

Church, G., and E. Regis. 2012. Regenesis: How Synthetic Biology Will Reinvent Nature and Ourselves. New York: Basic Books.

Crichton, M. [1969] 1993. The Andromeda Strain. New York: Random House.

Crichton, M. (Pseudonym: John Lange) 1970/2013. Drug of Choice. London: Titan Books.

Crichton, M. (Pseudonym: John Lange) 1972/2013. Binary. London: Titan Books.

Crichton, M. 1980. Congo. New York: Knopf.

Crichton, M. [1987] 1988. Sphere. New York: Ballantine.

Crichton, M. [1988] 2003. Travels. New York: Knopf.

Crichton, M. 1990. Jurassic Park. London: Arrow/Random House.

Crichton, M. 1994. Disclosure. New York: Knopf.

Crichton, M. [1995] 2002. The Lost World. New York: Knopf.

Crichton, M. 2002. Prey. New York: Avon.

Crichton, M. 2004. State of Fear. New York: HarperCollins.

Crichton, M. 2006. Next. New York: HarperCollins.

Crichton, M., and R. Preston. [2011] 2012. Micro. London: HarperCollins.

DeSalle, R., and D. Lindley. 1997. The Science of Jurassic Park and the Lost World; or, How to Build a Dinosaur. New York: Basic Books.

Ellmann, M., ed. 1991. Psychoanalytic Literary Criticism. London: Longman.

Franklin, S. 2000. "Life Itself: Global Nature and the Genetic Imaginary." In Global Nature, Global Culture, edited by S. Franklin, C. Lury, and J. Stacey, 188-227. London: Routledge.

Freeland, C. A. 1996. "Feminist Frameworks for Horror Films." In Post-theory: Reconstructing Film Studies, edited by N. Carroll and D. Bordwell, 195-218. Madison: University of Wisconsin Press.

Freud, S. [1908] 1941. "Der Dichter und das Phantasieren [Creative Writers and Day-Dreaming]." In Gesammelte Werke VII, edited by S. Freud, 213-223. London: Imago.

Freud, S. [1909] 1941. "Der Familienroman der Neurotiker [Family Romances].” In Gesammelte Werke VII, edited by S. Freud, 227-234. London: Imago.

Freud, S. [1910] 1943. “Über 'wilde' Psychoanalyse ['Wild' Psycho-analysis].” In Gesammelte Werke VIII, edited by S. Freud, 118-125. London: Image.

Freud, S. [1917] 1940. "Die Wege der Symptombildung." In Vorlesungen zur Einführung in der Psychoanalyse [Introductory Lectures on Psycho-analysis], edited by S. Freud, 372-391. London: Imago. 


\section{H.A.E. (Hub) Zwart}

Freud, S. [1926] 1948. "Die Frage der Laienanalyse. Unterredungen mit einem Unparteiischen [The Question of Lay Analysis]." In Gesammelte Werke XIV, edited by S. Freud, 207-297. London: Imago.

Haraway, D. 1989. Primate Visions: Gender, Race and Nature in the World of Modern Science. New York: Routledge.

Husserl, E. [1935] 1977. Die Krisis der europäischen Wissenschaften und die transzendentale Phänomenologie [The Crisis of European Sciences and Transcendental Phenomenology], edited by E. Ströker. Hamburg: Meiner.

Ju, A. 2008. "Jurassic Park and the Moral Character of the Scientist." Humanitas (Autumn): 26-30.

Kofman, S. [1974] 1991. Freud and Fiction. Cambridge: Polity Press.

Lacan, J. 1966. Écrits. Paris: Éditions du Seuil.

Lacan, J. 1991. Le séminaire, livre XVII: L'envers de la psychanalyse (1969-1970). Paris: Éditions du Seuil.

Luck-Baker, A. 1993. "Taking the Temperature of T-Rex.” New Scientist 139: 15.

Mawer, S. 2005. "Science in Literature: Interview." Nature 434: 297-299. doi:10.1038/434297a.

Morrison, P. 1994. "From Dinophobia to Gynophobia: Michael Crichton's Latest Novel Takes a New Angle on Gender Equality in the Workplace." Los Angeles Times, January 16.

Nerlich, B. 2005. "From Nautilus to Nanobo(a)ts: The Visual Construction of Nanoscience." http:// azonan.com.

Nerlich, B., D. Clarcke, and R. Dingwall. 2001. "Fiction, Fantasies and Fears: The Literary Foundations of the Cloning Debate." Journal of Literary Semantics 30 (1): 37-52.

Rohn, J. 2006. "Experimental Fiction." Nature 439 (19): 269.

Stern, M. 2004. "Jurassic Park and the Moveable Feast of Science." Science as Culture 13 (3): $347-372$.

Trembley, E. 1996. Michael Crichton: A Critical Companion. Westport, CT: Greenwood Press.

Urban, B., and W. Kudszus, eds. 1981. Psychoanalytische und Psychopathologische Literaturinterpretation. Darmstadt: Wissenschaftliche Buchgesellschaft.

Vermeulen, N., S. Tamminen, and A. Webster. 2012. Bio-objects - Life in the 21st Century. Farnham: Ashgate.

Whalan, M. 2007. Race, Manhood, and Modernism in America: The Short Story Cycles of Sherwood Anderson and Jean Toomer. Knoxville: University of Tennessee Press.

Wright, E. 1984. Psychoanalytic Criticism: Theory and Practice. London: Methuen.

Žižek, S. [2006] 2007. How to Read Lacan. New York: Norton.

Zwart, H. 2008. Understanding Nature. Case Studies in Comparative Epistemology. Dordrecht: Springer.

Zwart, H. 2013. "The Genome as the Biological Unconscious - and the Unconscious as the Psychic 'Genome'. A Psychoanalytical Reading of Molecular Genetics." Cosmos and History: Journal of Natural and Social Philosophy 9 (2): 198-222. 